\title{
Магнитоэлектрическая микрокриогенная система с комбинированным регенератором, работающая по обратному циклу Стирлинга для криостатирования фотоприёмных устройств
}

\author{
А.В. Самвелов, С.Г. Ясев, А.С. Москаленко, К.С. Павлов \\ Акционерное общество «Оптико-механическое конструкторское бюро «АСТРОН», \\ Московская область, г. Лыткарино, 140080, ул. Парковая, 1 \\ тел./факс: +7 (495) 941-62-72, эл. почта: v@astrohn.ru
}

DOI 10.34077/RCSP2019-33

Редкоземельные металлы обладают особыми физическими свойствами и могут быть использованы для создания преобразователей энергии. Одним из примеров является магнитное охлаждение, на основе магнитокалорического эффекта (МКЭ). Он наблюдается при адиабатном размагничивании парамагнитного материала, обладающего хорошими магнитными свойствами при температурах вблизи температуры Кюри (Нееля), в частности, высоким МКЭ, когда в изотермических условиях рабочий элемент из такого материала намагничивается в магнитном поле, нагреваясь при этом, а затем, при съёме магнитного поля размагничивается, в процессе чего, охлаждаясь, обеспечивает криостатирование объекта.

Разработана магнитоэлектрическая микрокриогенная система (МКС) с комбинированным регенератором (рис.), работающая по обратному циклу Стирлинга для криостатирования фотоприёмных устройств (ФПУ) со ступенью окончательного охлаждения, работающей на МКЭ. Рабочее тело ступени предварительного охлаждения - газообразный гелий, рабочее тело ступени окончательного охлаждения - двухфункциональный лантаноидный регенератор, выполненный в «холодной» области из гольмия. В первой ступени реализуется обратный ц. Стирлинга, во второй ступени гелий окончательно охлаждается при снятия магнитного поля с МК-ступени (гольмиевой области регенератора) - процесс адиабатного размагничивания. «Холодная» область насадки регенератора, выполненная из гольмия, помимо реализации МК-эффекта, позволяет оптимизировать регенерацию обратного ц. Стирлинга за счёт повышения теплоёмкости гольмия вблизи температуры нормального кипения ж. азота.

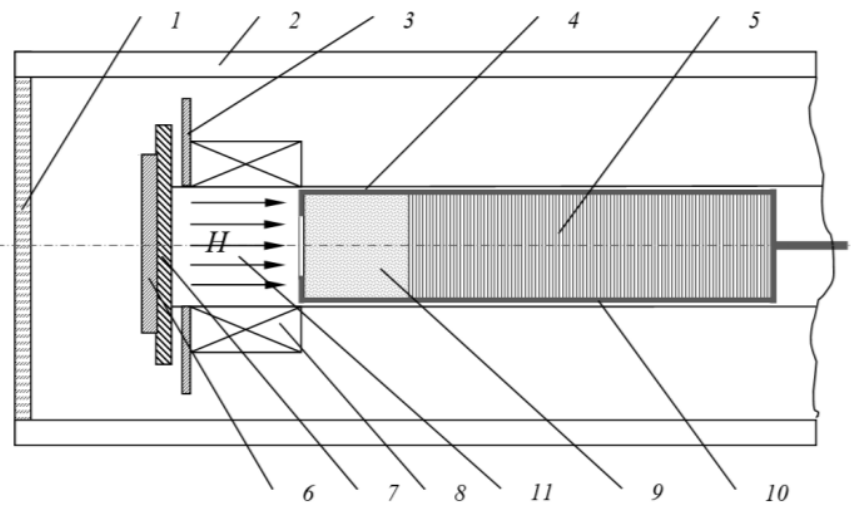

Рисунок. Охладитель МКС Стирлинга

с МК-ступенью охлаждения 1 - оптическое окно ФПУ; 2 - вакуумный теплозолирующий корпус; 3 - антимагнитный экран; 4 - детандер со встроенным регенератором; 5 - область насадки регенератора из традиционных сетчатых стальных дисков; 6 - ФПУ; 7 держатель ФПУ; 8 - активный магнитный элемент; 9 - парамагнитная область регенератора (гольмий); 10 - детандерный поршень.

Созданная МКС Стирлинга с МК-ступенью криостатирования позволяет расширить диапазон температур криостатирования до 90...60 К, повысить КПД МКС в этом диапазоне температур на 10$15 \%$, снизить потребляемую мощность на $15 \%$. Одновременно повышается эффективность регенерации тепла в активном регенераторе, а также дополнительное охлаждение во второй магнитокалорической ступени устройства. Т.о. достигается снижение температуры криостатирования до 60 К, уменьшение потребляемой мощности до 12-15 \% и повышение КПД на 8-10 \%.

\section{Лuтература}

[1] С.А. Никитин. Магнитные свойства редкоземельных металлов и их сплавов. М.: МГУ, 1989. $247 \mathrm{c}$.

[2] А.С. Андреенко и др. // Успехи физических наук. 1989. Т. 158, вып. 4. С. 553-579.

[3] Е.М. Савицкий. Металловедение редкоземельных металлов. М.: Наука, 1975. 272 с. 